\title{
PEMAHAMAN MENEJEMEN BENCANA SISWA SMP DI KABUPATEN SLEMAN
}

\author{
Agus Sudarsono \\ Satriyo Wibowo \\ Jurusan Pendidikan IPS, Fakultas Ilmu Sosial UNY \\ Email: satriyo@uny.ac.id, No.Hp. 081578704457
}

\begin{abstract}
Abstrak
Strategi penanggulangan bencana akan dapat berjalan dengan efektif apabila penduduk mempunyai pemahaman yang memadai mengenai menejemen dan mitigasi bencana. Wilayah Kabupaten Sleman sebagai wilayah yang rawan dengan bencana khususnya letusan gunung Berapi dan gempa bumi membutuhkan menejemen bencana yang komprehensif agar resiko bencana dapat ditekan seminimal mungkin apabila bencana melanda kawasan tersebut. Oleh karena itu, penelitian tentang pengetahuan menejemen bencana bagi siswa SMP di Kabupaten Sleman menjadi penting untuk dilakukan. Jenis penelitian ini adalah penelitian survey. Jenis penelitian ini dipilih karena peneliti hanya berusaha mengumpulkan informasi sederhana tentang menejemen kebencanaan yang ada di sekolah siaga bencana. Kemudian informasi tersebut dapat dijadikan sebagai bahan untuk menjelaskan fenomena sosial yang terjadi di sekolah. Penjelasan tentang hal penting mengingat pendidikan kebencanaan yang masih belum mendapatkan kesempatan yang memadai. Hasil penelitian menunjukkan bahwa pada umumnya siswa mempunyai pemahaman yang memadai tentang becana, khususnya becana alam gunung meletus, namun sebagian besar kurang mengetahui bencana alam tsunami dan gempa bumi tektonik. Responden mempunyai apresiasi positif terhadap sekolah sebagai sekolah siaga bencana. Mereka juga mengetahui bahwa sebagai sekolah siaga bencana, sekolah mempunyai beberapa fasilitas seperti: petunjuk evakuasi, alat peringatan dini, ruang perawatan korban, dan panduan kebencanaan. Persepsi mengenai sekolah siaga bencana juga menunjukkan respon yang sangat baik, dimana secara umum siswa mengetahui bahwa sekolah mereka merupakan sekolah siaga bencana (89\%). Mereka juga menganggap bahwa sekolah siaga bencana mempunyai peranan yang signifikan dalam mengurangi dampak resiko bencana (89\%). Fasilitas yang dimiliki oleh sekolah dirasakan masih kurang oleh siswa (47\%). Hal ini bisa jadi disebabkan adanya kesenjangan antara alat peraga, atau alat lainnya dengan jumlah siswa. Sekolah sudah dilengkapi dengan 3 buah alat peringatan dini bencana, papan petunjuk jalur evakuasi, modul bencana, dan alat komunikasi. Mereka berpendapat bahwa pemerintah diharapkan memberikan atau menyediakan alat peringatan dini bencana, bukan hanya di sekolah tetapi juga di berbagai tempat agar semua penduduk dapat mengetahui apabila bencana alam datang. Mereka juga mengharapkan agar alat-alat tersebut dikontrol apakah masih dapat berfungsi dengan baik atau tidak.
\end{abstract}

Kata kunci: menejemen bencana, mitigasi, bencana, 


\begin{abstract}
Disaster management strategies will work effectively if people have adequate understanding of disaster management and mitigation. Sleman as a disaster-prone area, especially volcanic eruptions and earthquakes require comprehensive disaster management for disaster risk can be minimized if disaster strikes the area. Therefore research on disaster management knowledge for junior high school students in Sleman becomes important to do. This type of research is survey research. This type of research was chosen because the researcher only tried to collect simple information about disaster management in disaster preparedness school. Then the information can be used as a material to explain the social phenomena that occur in schools. Explanation of the important thing considering disaster education that still not get adequate opportunity. The result of the research shows that in general the students have an adequate understanding of disaster, especially the eruption of natural volcanic eruptions, but most of them are less aware of the tsunami disaster and tectonic earthquake. Respondents have a positive appreciation of the school as a disaster preparedness school. They also know that as a disaster alert school, schools have several facilities such as evacuation instructions, early warning tools, victim care rooms, and disaster guides. The perception of disaster prepared schools also showed a very good response, wherein generally the students knew that their school was a disaster preparedness school (89\%). They also consider that disaster alert schools have a significant role in reducing the impact of disaster risk (89\%). The facilities owned by schools are still lacking by students (47\%). This may be due to a gap between props, or other tools with the number of students. The school is equipped with 3 tools of disaster early warning, evacuation route board, disaster module, and communication tool. They argue that the government is expected to provide or provide disaster early warning tools, not only in schools but also in various places so that all citizens can know when natural disasters come. They also expect the tools to be controlled whether they are functioning properly or not.
\end{abstract}

Keywords: disaster management, mitigation, disaster,

\title{
Pendahuluan
}

Fisiografi Indonesia terdiri dari beragam bentuk bentang lahan, mulai dari dataran rendah hingga dataran tinggi dan pegunungan. Indonesia terkenal memiliki pegunungan berapi yang selalu aktif sepanjang waktu. Deretan pegunungan tersebut memanjang sepanjang Sumatra, Jawa, Bali, Nusa Tenggara dan Maluku yang kemudian dikenal dengan deretan pengunungan sirkum mediteran dan juga terdapat jalur pegunungan aktif Fasifik yang membentang dari Filiphina masuk melalui Maluku hingga Laut Banda. Banyaknya pegunungan aktif ini tidak terlepas dari keberadaan Indonesia yang berada pada zona patahan lempeng besar dunia yaitu lempeng IndoAustralia dan Lempeng Asia serta lempeng Pasifik. Letak Indonesia 
yang demikian menimbulkan konsekwensi bahwa Indonesia adalah salah satu wilayah di dunia yang rawan akan terjadinya gempa bumi sebagai akibat pergerakan lempeng-lempeng tektonik tersebut. Tumbukan antar lempeng terjadi karena lempeng-lempeng tektonik tersebut selalu bergerak. Kita tidak pernah mengetahui kejadiankejadian yang akan terjadi di muka bumi ini. Munculnya banyak gunung berapi aktif juga sebagai indikator yang menguatkan bahwa wilayah Indonesia berada pada jalur pertemuan antar lempeng tektonik dimaksud. Salah satu gunung berapi yang aktif adalah gunung berapi Merapi yang berada di wilayah perbatasan Jogjakarta dan Jawa Tengah. Kondisi banyaknya gunung berapi aktif dan letaknya yang tepat di zona patahan, menjadikan Indonesia sebagai salah satu negara yang memiliki tingkat rawan bencana alam yang sangat tinggi. Indonesia sendiri memiliki titik-titik gempa yang tersebar diseluruh wilayah di Indonesia. Mungkin kita merasa biasa saja dengan bencana alam tersebut di Indonesia, tapi bencana tersebut sudah sangat sering terjadi berulang-ulang di negara kita. Gempa bumi sudah menghancurkan sebagian dari wilayah Indonesia, dan sudah banyak sekali korban-korban yang berjatuhan akibat bencana tersebut. Berarti gempa bumi sudah menjadi suatu ancaman bagi masyarakat di muka bumi ini, dan banyak dari masyarakat tidak mengerti akan apa sebenarnya yang terjadi di muka bumi ini. Maka sangatlah perlu bagi mereka untuk tahu dan mengerti serta memahami peristiwa-peristiwa gempa bumi yang terjadi.

Menilik letak geografisnya, maka wilayah Indonesia rawan terjadi bencana alam. Masih membekas dalam ingatan semua orang bagaimana bencana tsunami meluluhlantakkan Aceh, yang disusul gempa bumi pada tahun 2006 yang memporakporandakan wilayah Yogyakarta. Tanah air kita memang sunguh-sungguh dihadapkan pada resiko bencana alam yang meningkat dalam waktu yang bersamaan. Secara geografis Indonesia sangat rawan terjadi bencana alam baik yang berupa gempa, banjir, atau tsunami. Pertemuan lempeng Eurasia dan Indo-Australia berpotensi menyebabkan gempa tektonik, sedangkan curah hujan yang tinggi berpotensi rawan banjir mengingat banyaknya sungai di wilayah ini.

Daerah Istimewa Yogyakarta merupakan salah satu daerah rawan bencana gempa bumi di Indonesia. Resiko gempa bumi di DIY 
disebabkan letaknya yang berada di pertemuan lempeng Eurasia dan Indo-Australia. Gempa bumi pada 27 Mei 2006 yang melanda DIY dan sekitarnya pukul 05.55 WIB memberikan gambaran bahwa gempa bumi dapat terjadi kapanpun tanpa diduga. Gempa bumi ini menewaskan 6.234 jiwa, 46.000 orang luka-luka, serta 139.000 rumah/bangunan hancur. Gempa ini hanya terjadi dalam waktu 57 detik, namun telah menimbulkan kerugian yang besar (Ella dan Usman, 2008: 74). Kondisi di atas menggambarkan bahwa masyarakat DIY harus selalu waspada terhadap ancaman gempa bumi. Hal itu dikarenakan hingga saat ini belum ada satupun teknologi yang mampu memprediksi kapan dan di mana gempa bumi akan terjadi secara akurat. Kejadian gempa bumi pada tahun 2006 merupakan contoh nyata bahwa gempa bumi dapat terjadi kapanpun dan di manapun. Sebagai negara dengan potensi dan riwayat bencana alam yang tinggi seharusnya Indonesia mempunyai pengalaman belajar dan mengatasi bencana. Badan Nasional Penanggulangan Bencana (BNPB) mencatat bahwa setiap tahun Negara kita harus siap menghadapi bencana tidak kurang dari 500 bencana (BNPB: 2010). Hal yang dapat dipetik dari bencana alam yang dihadapi adalah bagaimana kita mempersepsikan terjadinya bencana alam dan bagaimanakah tingkat kerusakan yang mungkin timbul, serta bagaimanakah upaya dan respon untuk mengatasinya. Hal-hal tersebut perlu mendapatkan perhatian khususnya untuk daerahdaerah yang rawan bencana seperti Yogyakarta.

Manusia selalu dikelilingi oleh berbagai situasi yang dapat mengancam kesejateraan hidupnya. Situasi tersebut dapat dianggap sebagai situasi yang sangat berbahaya dan mengancam, dapat pula dianggap sebagai situasi yang tidak berbahaya. Penilaian terhadap berbagai situasi tersebut terkait dengan persepsi risiko terhadap bencana yang akan dihadapi. Hal ini penting untuk diketahui agar dapat ditelaah mengenai hal-hal yang dianggap sebagai risiko bencana. Kerugian akibat bencana bertambah apabila masyarakat belum mengerti upaya untuk mengurangi resiko bencana atau yang dikenal dengan mitigasi bencana. Mitigasi bencana merupakan upaya untuk mengurangi dampak bencana. Mitigasi ini terdiri dari mitigasi fisik (struktural) yaitu upaya mengurangi dampak bencana secara fisik dan mitigasi non fisik (nonstruktural) yaitu upaya mengurangi 
dampak bencana seccara non fisik yang diwujudkan dalam pendidikan mitigasi bencana (Radianta Triatmadja, 2010:141).

Strategi penanggulangan bencana akan dapat berjalan dengan efektif apabila penduduk mempunyai pemahaman yang memadai mengenai menejemen dan mitigasi bencana. Wilayah Kabupaten Sleman sebagai wilayah yang rawan dengan bencana khususnya letusan gunung Berapi dan gempa bumi membutuhkan menejemen bencana yang komprehensif agar resiko bencana dapat ditekan seminimal mungkin apabila bencana melanda kawasan tersebut. Oleh karena itu penelitian tentang pengetahuan menejemen bencana bagi siswa SMP di Kabupaten Sleman menjadi penting untuk dilakukan.

\section{Persepsi Resiko}

Persepsi merupakan gambaran yang ada dalam setiap inidividu terhadap objek tertentu. Persepsi mengandaikan objek pada keadaan tertentu yang berangkat dari pengalaman, indera, atau informasi. Slameto (2010: 102) menyatakan: "persepsi adalah proses yang menyangkut masuknya pesan atau informasi ke dalam otak manusia". Pendapat ini menekankan pada sebuah proses masuknya suatu pesan ke dalam otak manusia. Sugihartono (2007:8) "persepsi merupakan kemampuan untuk menterjemahkan stimulus". Stimulus yang dimaksud dalam pendapat ini merupakan suatu rangsangan dari luar diri manusia yang mempunyai pengaruh signifikan terhadap pembentukan opini, pendapat, dan persepsi manusia.

Bimo Walgito (2004: 87-88) memberikan penjelasan bahwa persepsi sebagai suatu proses yang diawali penginderaan untuk menerima stimulus melalui alat indera atau disebut proses sensoris kemudian dilanjutkan dengan proses persepsi. Dalam proses persepsi yang dijelaskan Bimo, terdapat proses yang mengawali persepsi yaitu penginderaan. Miftah Toha (1983: 141-143) menyebutkan bahwa persepsi merupakan proses kognitif yang dialami seseorang untuk memahami lingkungan baik melalui penglihatan, pendengaran, penghayatan, perasaan, dan penciuman. Lebih lanjut Miftah Thoha (1983: 143) menyebutkan bahwa persepsi lebih kompleks dan luas jika dibandingkan dengan penginderaan.

Berdasarkan pendapat tersebut, dapat disimpulkan bahwa persepsi merupakan sebuah proses yang berupa respon terhadap 
rangsangan atau stimulus dari luar. Respon ini dapat berupa pendapat, tindakan, atau bahkan dalam bentuk penolakan terhadap suatu stimulus. Proses penginderaan hanya merupakan langkah awal proses persepsi, serta penginderaan memberikan gambaran nyata mengenai suatu objek sedangkan persepsi mampu memahami lebih dari gambaran nyata objek tersebut.

Sementara itu resiko dapat didefinisikan sebagai suatu situasi dimana sesuatu dari nilai-nilai kemanusiaan berada dalam taruhan dan dimana hasilnya tidak memiliki kepastian (Sjoeberg, Moen, Rundmo, 2004). Sementara Karena Brun (1994) berpendapat bahwa resiko terkadang didesinisikan sebagai kekurangan dari kegiatan pengontrolan. Dengan demikian resiko sangat tergantung dari persepsi masing-masing individu. Resiko juga dapat dinyatakan sebagai situasi dimana seseorang mengalami akibat dari suatu bahaya.

Dari berbagai definisi tentang persepsi dan resiko, maka persepsi resiko dapat diartikan sebagai penilaian subjektif terhadap probabilitas dari jenis kecelakaan tertentu dan seberapa peduli kita dengan konsekuensi tersebut. Persepsi resiko melampaui individu dan merupakan konstruki sosial budaya yang mencerminkan nilainilai, symbol-simbol, sejarah, dan ideologi (Weinstein, 1989). Pengalaman pribadi, ingatan, dan faktor lain mempengaruhi cara masyarakat dalam mempersepsikan resiko dan dapat mengacuhkan probabilitas dampak. Hal ini dipengaruhi oleh beberapa faktor:

a) Potensi dampak, dimana seseorang akan memperhatikan kecelakaan fatal dan cedera dalam skala besar bila dibandingkan kecelakaan dalam skala kecil.

b) Kelaziman, dimana seseorang akan memperhatikan resiko yang tidak lazim seperti kebocoran Ozon daripada resiko yang lazim terjadi seperti kecelakaan lalu lintas.

c) Kesukarelaan, dimana orang akan lebih rela terpapar resiko yang menyenangkan dibandingkan sebaliknya.

d) Dapat dimengerti, dimana orang akan lebih memperhatikan kegiatan yang kurang dimengerti seperti terpapar radiasi daripada kegiatan yang dapat dimengerti oleh orang. 


\section{Bencana}

Bencana merupakan kejadian yang tidak biasa sulit direspon dan dampaknya bisa dirasakan oleh beberapa generasi. Bencana adalah peristiwa atau rangkaian peristiwa yang mengancam dan mengganggu kehidupan dan penghidupan masyarakat yang disebabkan, baik oleh faktor alam dan faktor non-alam maupun faktor manusia sehingga mengakibatkan timbulnya korban jiwa manusia, kerusakan lingkungan, kerugian harta benda, dan dampak psikologis. Definisi tersebut menyebutkan bahwa bencana disebabkan oleh faktor alam, non alam, dan manusia. Oleh karena itu, Undang-Undang Nomor 24 Tahun 2007 tersebut juga mendefinisikan mengenai bencana alam, bencana nonalam, dan bencana sosial.

Dilihat dari sifatnya, bencana dapat dikategorikan menjadi dua yaitu: bencana alam dan bencana akibat teknologi. Bencana dapat disebabkan oleh factor alam (natural disaster) atau oleh perbuatan manusia (man-made disaster). Faktor-faktor yang menyebabkan bencana antara lain bahaya alam dan bahaya karena perbuatan manusia, kerentanan (vulnerability) masyarakat, dan kapasitas yang rendah dari komponen masyarakat (Arnold, 1990). Menurut Badan Nasional Penanggulangan Bencana (2010) jenis-jenis bencana antara lain:

1) Gempa Bumi merupakan peristiwa pelepasan energi yang menyebabkan dislokasi (pergeseran) pada bagian dalam bumi secara tiba-tiba. Mekanisme perusakan terjadi karena energi getaran gempa dirambatkan ke seluruh bagian bumi. Di permukaan bumi, getaran tersebut dapat menyebabkan kerusakan dan runtuhnya bangunan sehingga dapat menimbulkan korban jiwa. Getaran gempa juga dapat memicu terjadinya tanah longsor, runtuhan batuan, dan kerusakan tanah lainnya yang merusak permukiman penduduk. Gempa bumi juga menyebabkan bencana ikutan berupa, kecelakaan industri dan transportasi serta banjir akibat runtuhnya bendungan maupun tanggul penahan lainnya.

2) Tsunami diartikan sebagai gelombang laut dengan periode panjang yang ditimbulkan oleh gangguan impulsif dari dasar laut. Gangguan impulsif tersebut bisa berupa gempa bumi tektonik, erupsi vulkanik atau longsoran. Kecepatan tsunami 
yang naik ke daratan (run-up) berkurang menjadi sekitar 25-100 $\mathrm{km} / \mathrm{jam}$ dan ketinggian air.

3) Letusan Gunung Berapi adalah merupakan bagian dari aktivitas vulkanik yang dikenal dengan istilah "erupsi". Hampir semua kegiatan gunung api berkaitan dengan zona kegempaan aktif sebab berhubungan dengan batas lempeng. Pada batas lempeng inilah terjadi perubahan tekanan dan suhu yang sangat tinggi sehingga mampu melelehkan material sekitarnya yang merupakan cairan pijar (magma). Magma akan mengintrusi batuan atau tanah di sekitarnya melalui rekahan-rekahan mendekati permukaan bumi. Setiap gunung api memiliki karakteristik tersendiri jika ditinjau dari jenis muntahan atau produk yang dihasilkannya. Akan tetapi apapun jenis produk tersebut kegiatan letusan gunung api tetap membawa bencana bagi kehidupan. Bahaya letusan gunung api memiliki resiko merusak dan mematikan.

4) Tanah Longsor merupakan salah satu jenis gerakan massa tanah atau batuan, ataupun percampuran keduanya, menuruni atau keluar lereng akibat dari terganggunya kestabilan tanah atau batuan penyusun lereng tersebut. Tanah longsor terjadi karena ada gangguan kestabilan pada tanah/batuan penyusun lereng.

5) Banjir dimana suatu daerah dalam keadaan tergenang oleh air dalam jumlah yang begitu besar. Sedangkan banjir bandang adalah banjir yang datang secara tiba-tiba yang disebabkan oleh karena tersumbatnya sungai maupun karena pengundulan hutan disepanjang sungai sehingga merusak rumah-rumah penduduk maupun menimbulkan korban jiwa.

6) Kekeringan adalah hubungan antara ketersediaan air yang jauh dibawah kebutuhan air baik untuk kebutuhan hidup, pertanian, kegiatan ekonomi dan lingkungan.

7) Angin Topan adalah pusaran angin kencang dengan kecepatan angin $120 \mathrm{~km} / \mathrm{jam}$ atau lebih yang sering terjadi di wilayah tropis diantara garis balik utara dan selatan, kecuali di daerahdaerah yang sangat berdekatan dengan khatulistiwa. Angin topan disebabkan oleh perbedaan tekanan dalam suatu sistem cuaca. Angin paling kencang yang terjadi di daerah tropis ini umumnya berpusar dengan radius ratusan kilometer di sekitar 
daerah sistem tekanan rendah yang ekstrem dengan kecepatan sekitar $20 \mathrm{~km} / \mathrm{jam}$. Di Indonesia dikenal dengan sebutan angin badai.

8) Gelombang Pasang adalah gelombang air laut yang melebihi batas normal dan dapat menimbulkan bahaya baik di lautan, maupun di darat terutama daerah pinggir pantai. Umumnya gelombang pasang terjadi karena adanya angin kencang atau topan, perubahan cuaca yang sangat cepat, dan karena ada pengaruh dari gravitasi bulan maupun matahari. Kecepatan gelombang pasang sekitar $10-100 \mathrm{~km} / \mathrm{jam}$. Gelombang pasang sangat berbahaya bagi kapal-kapal yang sedang berlayar pada suatu wilayah yang dapat menenggelamkan kapal-kapal tersebut. Jika terjadi gelombang pasang di laut akan menyebabkan tersapunya daerah pinggir pantai atau disebut dengan abrasi.

9) Kebakaran adalah situasi dimana suatu tempat atau lahan atau bangunan dilanda api serta hasilnya menimbulkan kerugian. Sedangkan lahan dan hutan adalah semua kejadian bencana yang diakibatkan oleh kesalahan desain, pengoperasian, kelalaian dan kesengajaan manusia dalam penggunaan teknologi atau industri. keadaan dimana lahan dan hutan dilanda api sehingga mengakibatkan kerusakan lahan dan hutan serta hasil-hasilnya dan menimbulkan kerugian.

10) Aksi teror atau sabotase adalah semua tindakan yang menyebabkan keresahan masyarakat, kerusakan bangunan, dan mengancam atau membahayakan jiwa seseorang atau banyak orang oleh seseorang atau golongan tertentu yang tidak bertanggung jawab. Aksi teror atau sabotase biasanya dilakukan dengan berbagai alasan dan berbagai jenis tindakan seperti pemboman suatu bangunan/tempat tertentu, penyerbuan tiba-tiba suatu wilayah,tempat, dan sebagainya. Aksi teror atau sabotase sangat sulit dideteksi atau diselidiki oleh pihak berwenang karena direncanakan seseorang atau golongan secara diam-diam dan rahasia.

11) Epidemi, wabah dan kejadian luar biasa merupakan ancaman yang diakibatkan oleh menyebarnya penyakit menular yang berjangkit di suatu daerah tertentu. Pada skala besar, epidemi atau wabah atau Kejadian Luar Biasa (KLB) dapat 
mengakibatkan meningkatnya jumlah penderita penyakit dan korban jiwa. Beberapa wabah penyakit yang pernah terjadi di Indonesia dan sampai sekarang masih harus terus diwaspadai antara lain demam berdarah, malaria, flu burung, anthraks, busung lapar dan HIV/AIDS. Wabah penyakit pada umumnya sangat sulit dibatasi penyebarannya, sehingga kejadian yang pada awalnya merupakan kejadian lokal dalam waktu singkat bisa menjadi bencana nasional yang banyak adalah suatu kondisi dimana terjadi huru-hara atau kerusuhan atau perang atau keadaan yang tidak aman di suatu daerah tertentu yang melibatkan lapisan masyarakat, golongan, suku, ataupun organisasi tertentu. enimbulkan korban jiwa. Kondisi lingkungan yang buruk, perubahan iklim, makanan dan pola hidup masyarakat yang salah merupakan beberapa faktor yang dapat memicu terjadinya bencana ini.

\section{Menejemen Bencana}

Manajemen bencana merupakan seluruh kegiatan yang meliputi aspek perencanaan dan penanggulangan bencana, pada sebelum, saat dan sesudah terjadi bencana yang dikenal sebagai Siklus Manajemen Bencana (seperti terlihat dalam Gambar Siklus Manajemen Bencana), yang bertujuan untuk (1) mencegah kehilangan jiwa; (2) mengurangi penderitaan manusia; (3) memberi informasi masyarakat dan pihak berwenang mengenai risiko, serta (4) mengurangi kerusakan infrastruktur utama, harta benda dan kehilangan sumber ekonomis (Agus Rahmat, 2015).

Penanganan bencana pada dasarnya di tujukan sebagai upaya untuk meredam dampaknya dan memperkecil korban jiwa, kerusakan dan kerugian yang diakibatkan oleh bencana. Jadi penanganan bencana bukan mencegah untuk terjadinya melainkan mencegah dampak atau akibat yang ditimbulkan oleh bencana dan memperkecil korban jiwa, kerugian secara ekonomis dan kerusakannya. Sudah sejak lama masyarakat tradisional bisa mengantisipasi terjadinya bencana karena mereka mampu melakukan prediksi, previsi dan preservasi secara langsung.

Manajemen bencana meliputi tahap-tahap sebagai berikut : 1) Sebelum bencana terjadi, meliputi langkah-langkah pencegahan, mitigasi, kesiapsiagaan dan kewaspadaan. 2) Pada waktu bencana 
sedang atau masih terjadi, meliputi langkah-langkah peringatan dini, penyelamatan, pengungsian dan pencarian korban. 3) Sesudah terjadinya bencana, meliputi langkah penyantunan dan pelayanan, konsolidasi, rehabilitasi, pelayanan lanjut, penyembuhan, rekonstruksi dan pemukiman kembali penduduk. Tahapan diatas dalam kenyataannya tidak dapat ditarik tegas antara tahapan satu ketahapan berikutnya. Demikian pula langkah- langkah yang diambil belum tentu dapat dilaksanakan secara berturut-turut dan runtut. Namun jelas bahwa manajemen bencana adalah suatu kegiatan atau rangkaian kegiatan yang menyeluruh, terpadu dan berlanjut yang merupakan siklus kegiatan. Sugiharyanto, dkk. (2014), dalam penelitian berjudul Persepsi Mahasiswa Pendidikan IPS Terhadap Mitigasi Bencana Gempa Bumi, Jipsindo, 2, 1, 161-182, menemukan bahwa persepsi mahasiswa Pendidikan IPS UNY terhadap mitigasi bencana gempa bumi berada pada kategori sangat baik sebesar 59,9\%, kategori baik sebesar 43,4\%, kategori cukup sebesar 0,7\%, dan kategori kurang sebesar 0\%. Kesimpulan untuk masing-masing indikator dapat dirinci sebagai berikut: (1) Persepsi mahasiswa Pendidikan IPS terhadap mitigasi struktural bencana gempa bumi sebesar 56,6\% berkategori sangat baik, 41,5\% berkategori baik, dan 5,9\% berkategori cukup; (2) Persepsi mahasiswa Pendidikan IPS terhadap mitigasi nonstruktural bencana gempa bumi sebesar 50,6\% berkategori sangat baik, 48,7\% berkategori baik, dan 0,7\% berkategori cukup. Persepsi mahasiswa Pendidikan IPS terhadap mitigasi bencana gempa bumi berdasarkan angkatan atau tingkatan sebagai berikut: (a) Mahasiswa Pendidikan IPS angkatan 2012, sebesar $48,1 \%$ berkategori sangat baik, 50\% berkategori baik, dan 1,9\% berkategori cukup; (b) Mahasiswa Pendidikan IPS angkatan 2011, sebesar 52\% berkategori sangat baik dan 48\% berkategori baik; serta (c) Mahasiswa Pendidikan IPS angkatan 2010, sebesar 64\% berkategori sangat baik dan 36\% berkategori baik. Iffa Afifah (2012), Studi Persepsi Resiko Ibu Rumah Tangga Terhadap Gempa Bumi di Menteng, Jakarta menunjukkan bahwa persepsi resiko ibu rumah tangga terhadap gempa umumnya baik (51\%) sedangkan $49 \%$ sangat baik. Sedangkan pengalaman dalam menghadapi gempa bumi tahun $2011(12 \%)$ membentuk persepsi terhadap resiko terjadinya bencana alam. 


\section{Metode Penelitian}

Jenis penelitian yang dipilih yaitu penelitian survey yaitu: jenis penelitian yang mengumpulkan informasi tentang karakteristik, tindakan, pendapat dari sekelompok responden yang representative yang dianggap sebagai populasi (Masri Singarimbun \& Sofian Efendi, 1982: 8). Dalam penelitian survai informasi dikumpulkan dari responden dengan menggunakan kuesioner yang dibatasi pada survai sampel yang dianggap mewakili populasi. Penelitian survai dengan menggunakan kuesioner sekarang ini jarang dipergunakan karena kebanyakan lebih banyak menggunakan poll (jajak pendapat) terutama di dalam hubungannya dengan pemilihan umum atau pemilihan kepala daerah.

Jenis penelitian ini dipilih karena peneliti hanya berusaha mengumpulkan informasi sederhana tentang menejemen kebencanaan yang ada di sekolah siaga bencana. Kemudian informasi tersebut dapat dijadikan sebagai bahan untuk menjelaskan fenomena sosial yang terjadi di sekolah. Penjelasan tentang hal penting mengingat pendidikan kebencanaan yang masih belum mendapatkan kesempatan yang memadai.

Populasi dari penelitian ini adalah siswa SMP Negeri 1 Cangkringan Kabupaten Sleman. Jumlah populasi 365 siswa yang terdiri kelas VII sebanyak 123, kelas VIII 125, dan kelas XI 115. Sedangkan teknik pengambilan sample yaitu purposive sampling yaitu teknik sampel yang mempunyai tujuan khusus atau pertimbangan tertentu (Sugiyono, 2008: 124). Sampel penelitian ditentukan kelas XI dengan pertimbangan bahwa kelas tersebut telah mendapat pelatihan tentang kebencanaan, sedangkan kelas lainnya belum mendapatkannya. Teknik pengumpulan data yang digunakan pada penelitian ini adalah kuesioner atau angket. Teknik angket ini dipergunakan untuk memperoleh data tentang pemahaman menejemen bencana siswa SMP N 1 Cangkringan Kabupaten Sleman. Penelitian ini diukur menggunakan skala model Likert yaitu suatu instrumen pengukuran sikap yang terdiri dari satu daftar pertanyaan, dan responden harus membuat pertimbangan terhadap setiap pernyataan dan memilih respon dari tingkat setuju sampai tidak setuju (Oemar Hamalik, 2005:150). Kuesioner yang dipersiapkan oleh peneliti terdiri dari tiga bagian yaitu pertama 
bagian pemahaman bencana, sekolah siaga bencana, fasilitas sekolah siaga bencana, dan pelatihan-pelatihan kebencanaan.

Teknik analisis data yang digunakan pada penelitian ini adalah analisis deskriptif yang disajikan dalam bentuk persentase. Persentase digunakan untuk melihat karakteristik responden terhadap butir pernyataan yang digunakan. Suatu penelitian dilaksanakan didasarkan atas dasar keinginan untuk menjawab pertanyaan-pertanyaan penelitian atau untuk mengungkapkan fenomena sosial atau fenomena alami tertentu. Untuk mencapai tujuan tersebut, peneliti harus terlebih dahulu merumuskan hipotesa, mengumpulkan data, memproses data, membuat analisa dan interpretasi. Analisa data adalah proses penyederhanaan data ke dalam bentuk yang lebih mudah dibaca dan diinterpretasikan (Efendi dan Manning, 1989: 263).

Dalam proses pengolahan data hasil kuesioner biasanya digunakan statistik. Salah satu fungsi pokok statistik adalah menyederhanakan data penelitian yang amat besar jumlahnya menjadi informasi yang lebih sederhana dan lebih mudah dipahami. Selain itu, statistik dapat membandingkan hasil yang diperoleh dengan hasil yang terjadi secara kebetulan (by chance), sehingga memungkinkan peneliti untuk menguji apakah hubungan sistematis antara variabel-variabel yang diteliti, atau hanya terjadi secara kebetulan. Setelah data dianalisa dan informasi yang lebih sederhana diperoleh, hasil-hasilnya harus diinterpretasi untuk mencari makna dan implikasi yang lebih luas dari hasil-hasil penelitian. Analisa data yang paling sederhana dalam statistik adalah analisa satu variabel (tabel frekuensi) dan analisa dua variabel (tabulasi silang).

\section{Hasil Penelitian}

SMP Negeri 1 Cangkringan berlokasi di desa Sariharjo, Kecamatan Cangkringan, Kabupaten Sleman tepatnya 8 Kilometer dari gunung berapi Merapi. Sekolah tersebut merupakan salah satu sekolah siaga bencana (SSB) disamping beberapa sekolah lain baik di tingkat SMA, dan SD. Di sekolah-sekolah tersebut materi kebencanaan baik gunung meletus, gempa bumi, maupun banjir, tsunami diajarkan dengan cara diintegrasikan dengan materi pembelajaran yang sesuai misalnya: IPA, IPS, Agama, PKn, dan lainlain. BPPD Sleman juga memberikan fasilitas penanganan kebencanaan seperti modul kebencanaan, alat-alat peraga, dan 
pelatihan penanggulangan bencana secara berkala dan berencana. Oleh karenanya pemilihan SMP Negeri 1 Cangkringan sebagai tempat penelitian dianggap penting mengingat daerah Cangkringan yang termasuk daerah rawan bencana.

Angket yang disusun tim peneliti yang secara garis besar dapat dikategorikan ke dalam 4 hal yaitu: pemahaman tentang bencana, kondisi sekolah siaga bencana, pelatihan kebencanaan, dan perilaku siswa ketika menghadapi bencana. Dari 100 angket yang disebarkan, semuanya telah mengembalikan angket yang telah diberikan pada saat pengambilan data. Angket diberikan kepada kelas IX dengan pertimbangan bahwa kelas tersebut telah sering terlibat dalam pelatihan kebencanaan. Responden juga selalu mengikuti kegiatankegiatan kebencanaan yang diadakan oleh sekolah maupun instansi di luar sekolah.

1. Pemahaman Bencana

Pada umumnya siswa mempunyai pemahaman yang memadai tentang becana, khususnya becana alam gempa bumi, namun sebagian besar kurang mengetahui bencana alam tsunami dan gunung meletus. Pertanyaan tentang pemahaman bencana tertuang dalam item angket nomor: 1, 6, 10, 16, dan 28. Berikut grafik pemahaman bencana dari siswa SMP N 1 Cangkringan

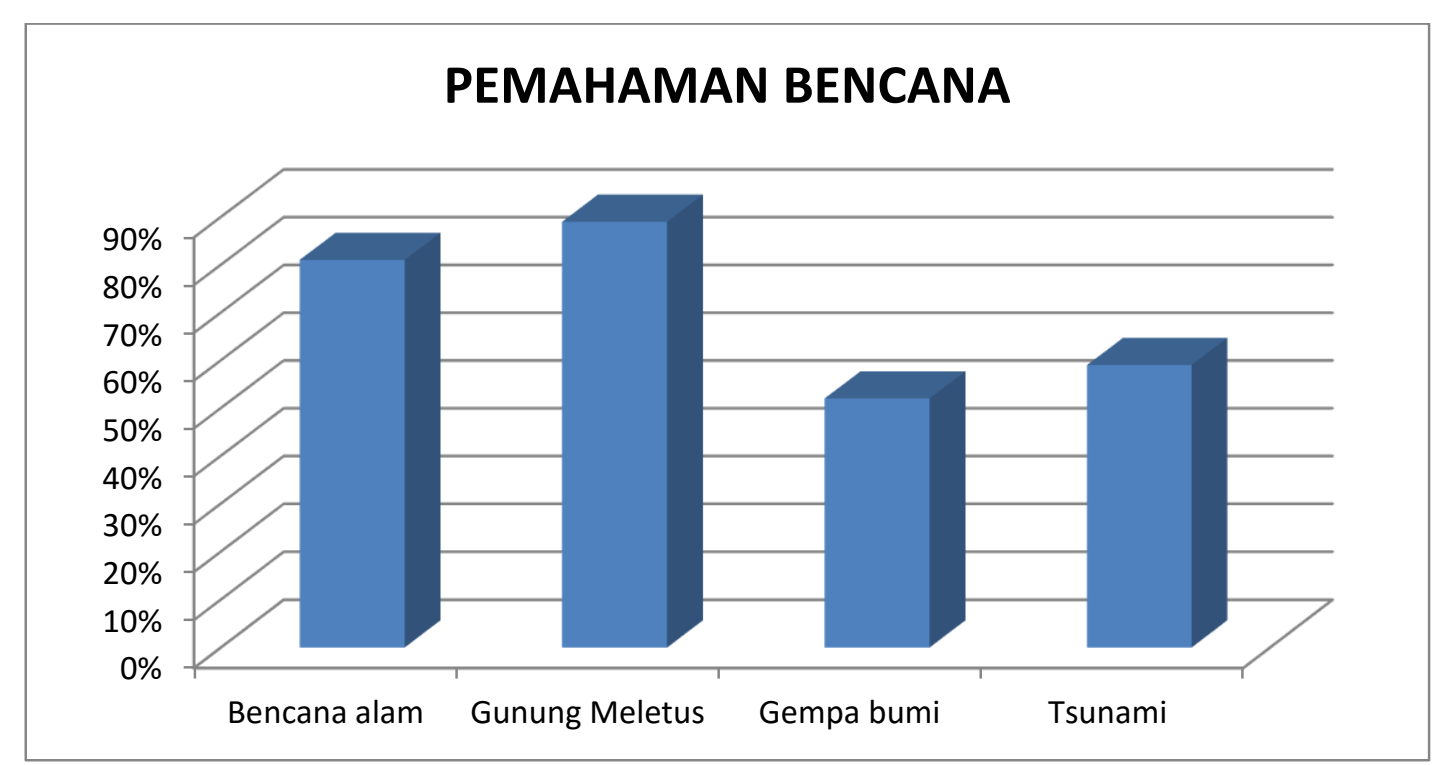

Grafik 1. Pengetahuan Bencana Siswa SMP N 1 Cangkringan

\section{Sekolah Siaga Bencana}

Pada umumnya siswa mempunyai apresiasi positif terhadap sekolah sebagai sekolah siaga bencana. Responden juga mengetahui bahwa sebagai sekolah siaga bencana, sekolah mempunyai beberapa fasilitas seperti: petunjuk evakuasi, alat 
peringatan dini, ruang perawatan korban, dan panduan kebencanaan. Pertanyaan tentang sekolah siaga bencana tersebar dalam 18 item yaitu: nomor, 2, 3, 4, 5, 7, 8, 9, 11, 12, 19, 20, 21, $24,26,27$. Respons siswa terhadap item-item tersebut dapat dilihat dari tabel berikut ini. Berikut grafik pemahaman sekolah siaga bencana dari siswa SMP N 1 Cangkringan:

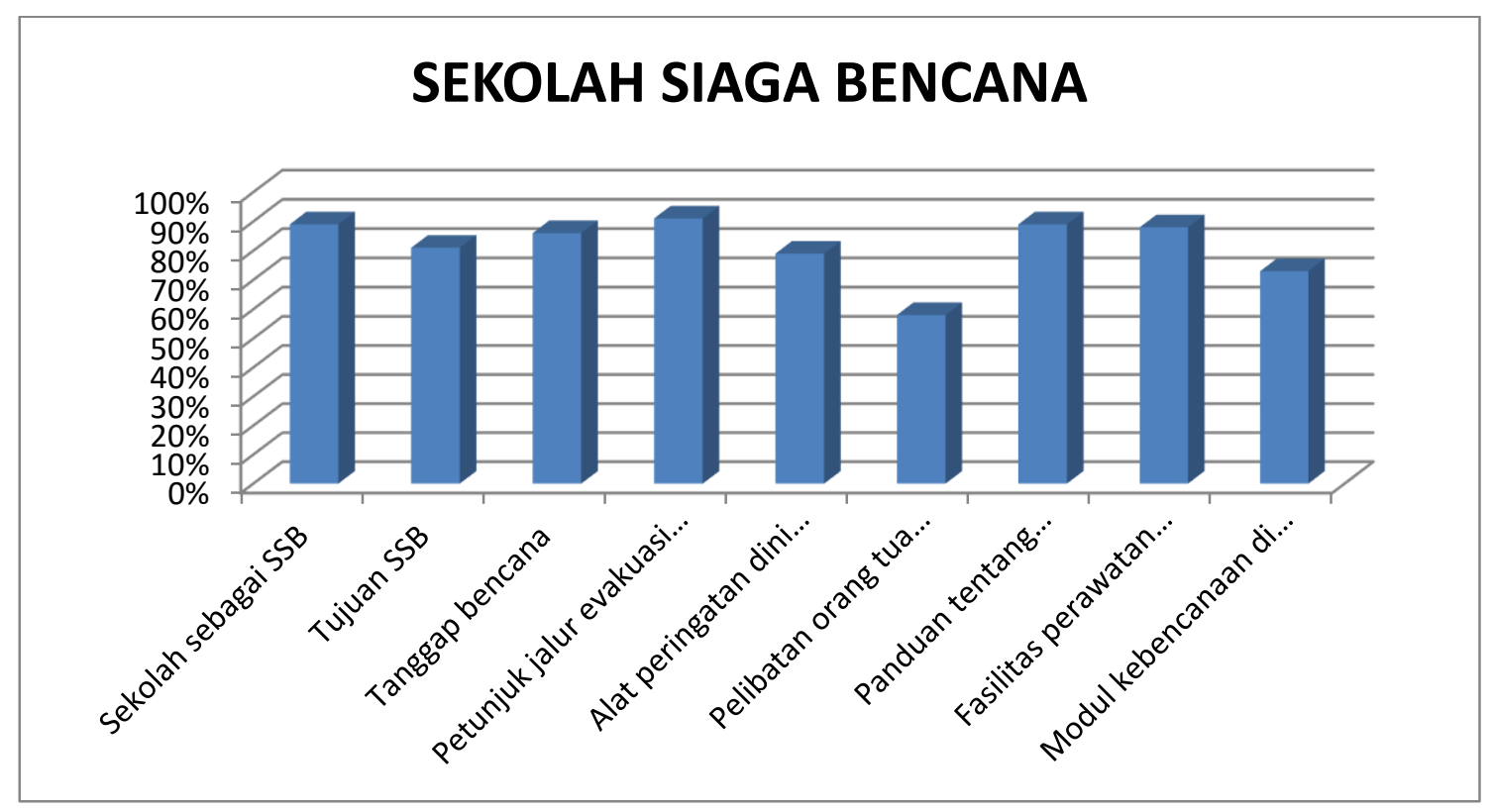

Grafik 2. Apresiasi Sekolah Siaga Bencana

\section{Pelatihan Kebencanaan}

Pada umumnya siswa berpendapat bahwa pelatihan kebencanaan yang diadakan oleh sekolah dianggap penting. Responden juga sangat setuju dengan adanya pelatihan-pelatihan tersebut karena dianggap sangat berguna untuk persiapan menghadapi bencana yang datang sewaktu-waktu. Pertanyaan tentang pelatihan kebencanaan ditunjukkan dengan item nomor: 4, $5,7,8,20$, dan 21. Berikut grafik pelatihan kebencanaan siswa SMP N 1 Cangkringan: 


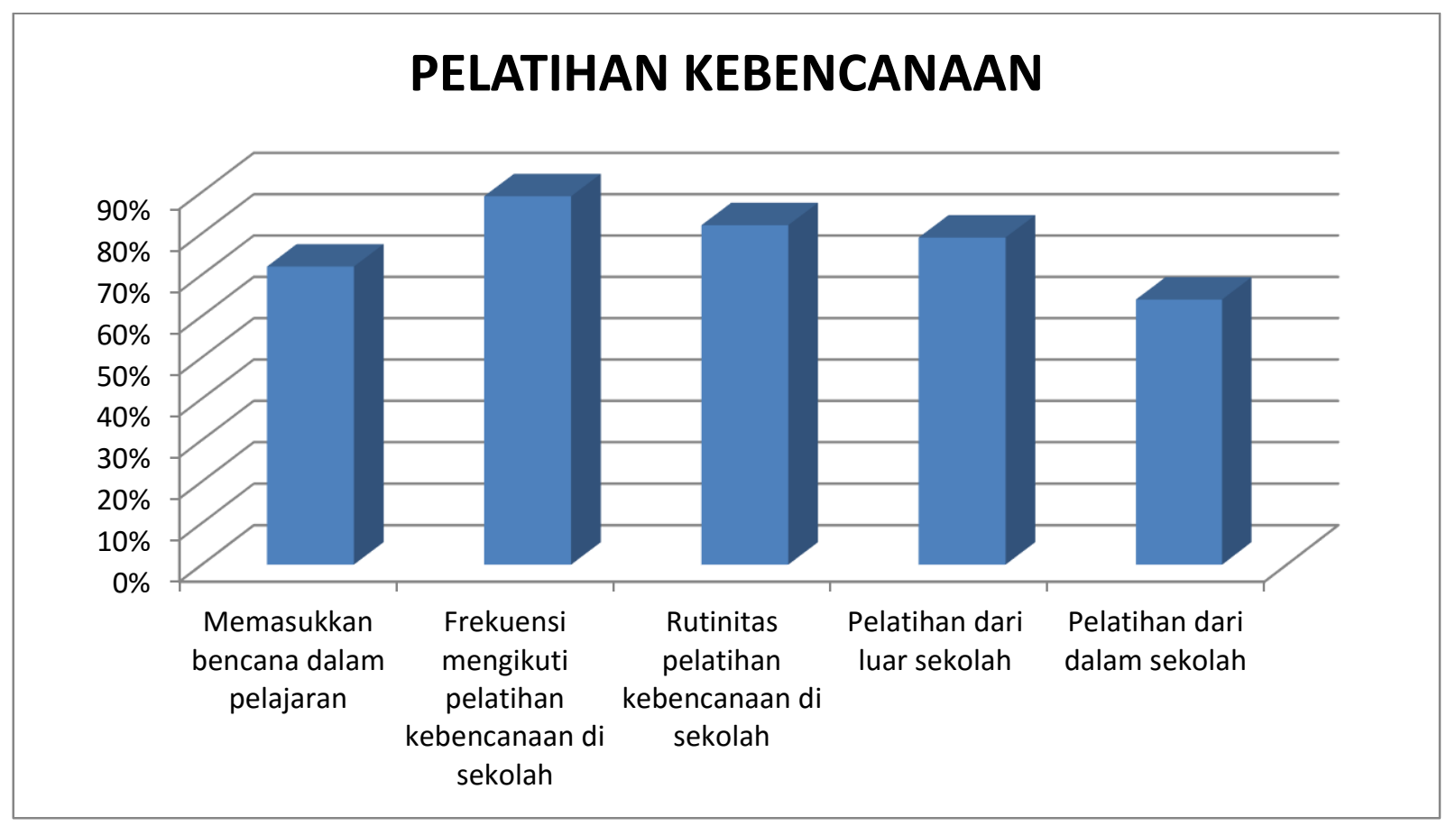

Grafik 3. Pelatihan Kebencanaan

4. Sikap Menghadapi Bencana

Pada umumnya siswa sudah mempunyai pemahaman yang memadai tentang menejemen bencana. Sikap responden dapat ditujukan dengan takut dan panik dan lari. Pertanyaan tentang sikap dalam menghadapi bencana ditunjukkan oleh item nomor: 13, $14,15,17,23$. Hasil angket dari pertanyaan-pertanyaan tersebut dapat digambarkan dengan grafik berikut

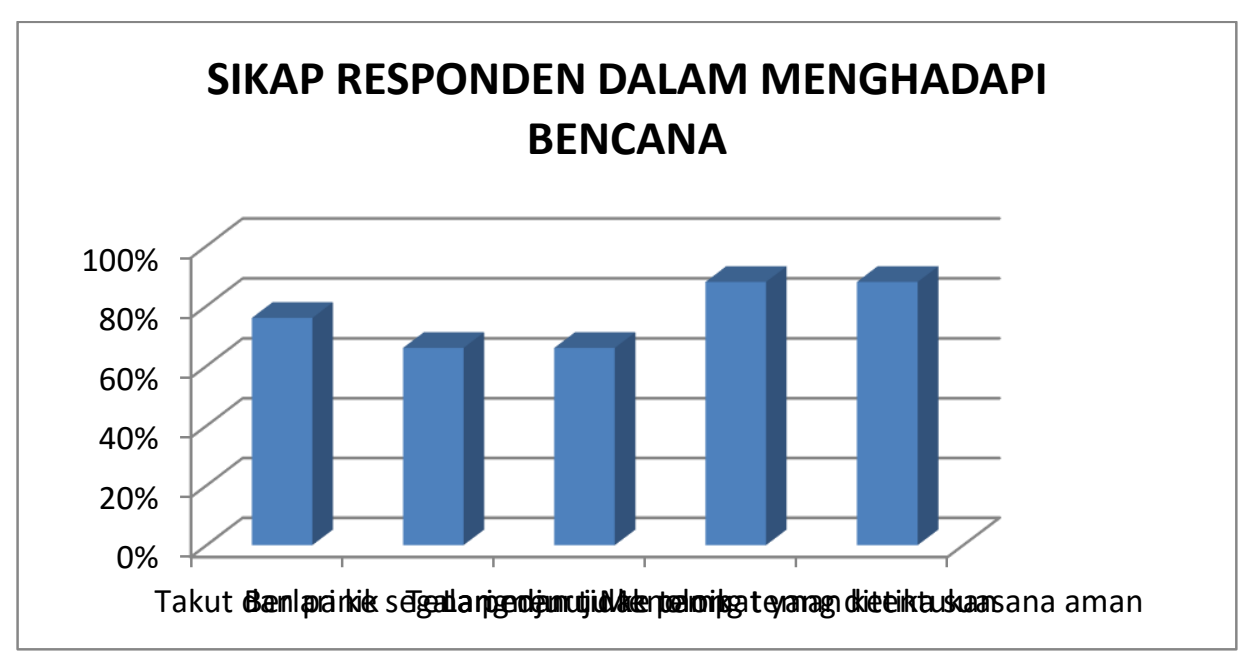

Sumber: Data primer

Grafik 4. Sikap Responden Dalam Menghadapi Bencana

\section{Pembahasan}

Pemahaman tentang bencana merupakan aspek yang penting bagi siswa karena pemahaman dan pengetahuan yang memadai tentang bencana akan memberikan referensi yang benar juga dalam bersikap dan bertindak. Pemahaman yang memadai juga akan memberikan efek reduksi korban bencana, khususnya korban nyawa 
manusia. Hal ini sejalan dengan gagasan Garvin (2001: 450) yang menyatakan bahwa pengalaman pribadi, ingatan dan faktor lainnya mempengaruhi cara masyarakat mempersepsikan resiko dan dapat mengacuhkan probababilitas atau peluang terjadinya dampak. Bencana gunung berapi Merapi terahir paling besar terjadi pada tahun 2010 dengan mengeluarkan "Wedhus Gembel" dan lahar panas yang memakan beberapa korban meninggal dunia dan menghancurkan permukiman di Dusun Turgo yang memaksa penduduk pada radius $15 \mathrm{Km}$ dari kawah Merapi untuk mengungsi dan sebagian kemudian direlokasi ke tempat permukiman baru yang aman. Sementara itu di daerah Bantul khusunya wilayah Imogiri mempunyai pengalaman traumatik dengan bencana alam berupa gempa bumi yang terjadi pada tanggal 27 Mei 2006. Patahan berupa sungai Oya dan Opak yang memanjang di Imogiri memberikan getaran yang sangat kuat hingga merusak bangunan (rumah penduduk) dan fasilitas umum lainnya. Hal inilah barangkali yang menyebabkan pemahaman masyarakat terhadap bencana alam gunung meletus dan gempa bumi sangat baik. Hal ini berbeda dengan jenis bencana lainnya seperti tsunami yang belum pernah responden alami.

Diantara jenis-jenis bencana yang dipahami dengan baik oleh siswa adalah bencana gunung meletus, sedangkan jenis bencana lain kurang dipahami (gempa bumi: 59\%, dan tsunami: 52\%). Dilihat dari persentasenya, maka lebih dari 50\% siswa mempunyai pemahaman yang baik mengenai bencana. Pemahaman responden ini diperoleh melalui pelajaran di sekolah, modul kebencanaan, dan pelatihanpelatihan yang diadakan oleh sekolah dan lembaga lain. Selain itu faktor keterbukaan informasi terutama media massa berupa televisi dan surat kabar mempunyai andil yang sangat besar dalam memberikan informasi dan pengetahuan terhadap bencana alam dan mitigasi yang harus dilakukan.

Persepsi mengenai sekolah siaga bencana juga menunjukkan respon yang sangat baik, dimana secara umum siswa mengetahui bahwa sekolah responden merupakan sekolah siaga bencana $(89 \%)$. Responden juga menganggap bahwa sekolah siaga bencana mempunyai peranan yang signifikan dalam mengurangi dampak resiko bencana (89\%). Bagi siswa pembentukan sekolah siaga bencana di kabupaten Bantul yang terdiri dari tiga sekolah 
merupakan langkah strategis untuk melakukan upaya pendidikan lingkungan sekaligus pendidikan kebencanaan meskipun materinya diintegrasikan dengan mata pelajaran lain seperti IPS, dan IPA. Sebagian besar siswa (72\%) siswa menyatakan sangat setuju apabila materi tentang bencana dijadikan sebagai mata pelajaran baru dengan nama pendidikan kebencanaan. Responden menganggap hal tersebut perlu karena responden tinggal di daerah rawan bencana sehingga mempunyai pemahaman yang baik tentang bencana alam.

Fasilitas yang dimiliki oleh sekolah dirasakan masih kurang oleh siswa (47\%). Hal ini bisa jadi disebabkan adanya kesenjangan antara alat peraga, atau alat lainnya dengan jumlah siswa. Sekolah sudah dilengkapi dengan 3 buah alat peringatan dini bencana, plang jalur evakuasi, modul bencana, dan alat komunikasi. Responden berpendapat bahwa pemerintah diharapkan memberikan atau menyediakan alat peringatan dini bencana, bukan hanya di sekolah tetapi juga di berbagai tempat agar semua penduduk dapat mengetahui apabila bencana alam datang. Responden juga mengharapkan agar alat-alat tersebut dikontrol apakah masih dapat berfungsi dengan baik atau tidak.

Pelatihan kebencanaan juga dianggap penting dimana $89 \%$ responden menyatakan sangat setuju apabila kegiatan pelatihan tersebut diadakan rutin. Namun para siswa berharap agar pelatihan yang dilaksanakan di sekolah mendatangkan instruktur dari luar sekolah.Simulai tentang kebencanaan juga dianggap penting sehingga dianggap penting untuk dilaksanakan. Simulasi bencana gempa, tsunami, dan erupasi gunung Merapi perlu disimulasikan agar ketika bencana tersebut betul-betul datang, responden tidak lagi panik dan bingung.

Hal terakhir yang ditanyakan adalah sikap dan perilaku siswa ketika terjadi bencana. Sebanyak $76 \%$ responden menyatakan panik dan takut apabila terjadi bencana alam. Sikap ini barangkali berangkat dari pengalaman responden ketika terjadi bencana beberapa waktu yang lalu seperti bencana gempa bumi 2006. Namun meskipun menyatakan panik dan takut, responden menyatakan sangat setuju untuk tidak berlari ke segala arah (83\%). Responden menyatakan sangat setuju untuk lari dan berkumpul di tempat tertentu. Hal ini barangkali merupakan dampak dari berbagai pelatihan dan simulasi bencana sehingga responden sudah 
mempunyai pemahaman yang memadai tentang perilaku dan sikap yang sesuai ketika terjadi bencana.

\section{SIMPULAN}

Daerah Istimewa Yogyakarta (DIY) merupakan salah satu daerah rawan bencana baik bencana gempa bumi maupun bencana erupsi gunung berapi (Merapi) di Indonesia. Kejadian gempa bumi pada tahun 2006 dan gunung merapi meletus pada 2010 merupakan contoh nyata bahwa gempa bumi dan gunung api meletus dapat terjadi kapanpun dan di manapun. Sebagai negara dengan potensi dan riwayat bencana alam yang tinggi seharusnya Indonesia mempunyai pengalaman belajar dan mengatasi bencana. Badan Nasional Penanggulangan Bencana (BNPB) mencatat bahwa setiap tahun Negara kita harus siap menghadapi bencana tidak kurang dari 500 bencana (BNPB: 2010). Hal yang dapat dipetik dari bencana alam yang dihadapi adalah bagaimana kita mempersepsikan terjadinya bencana alam dan bagaimanakah tingkat kerusakan yang mungkin timbul, serta bagaimanakah upaya dan respon untuk mengatasinya.

Hasil penelitian menunjukkan bahwa pada umumnya siswa mempunyai pemahaman yang memadai tentang becana, khususnya becana alam gunung meletus, namun sebagian besar kurang mengetahui bencana alam tsunami dan gempa bumi tektonik. Responden mempunyai apresiasi positif terhadap sekolah sebagai sekolah siaga bencana. Mereka juga mengetahui bahwa sebagai sekolah siaga bencana, sekolah mempunyai beberapa fasilitas seperti: petunjuk evakuasi, alat peringatan dini, ruang perawatan korban, dan panduan kebencanaan. Persepsi mengenai sekolah siaga bencana juga menunjukkan respon yang sangat baik, dimana secara umum siswa mengetahui bahwa sekolah mereka merupakan sekolah siaga bencana (89\%). Mereka juga menganggap bahwa sekolah siaga bencana mempunyai peranan yang signifikan dalam mengurangi dampak resiko bencana (89\%). Fasilitas yang dimiliki oleh sekolah dirasakan masih kurang oleh siswa (47\%). Hal ini bisa jadi disebabkan adanya kesenjangan antara alat peraga, atau alat lainnya dengan jumlah siswa. Sekolah sudah dilengkapi dengan 3 buah alat peringatan dini bencana, plang jalur evakuasi, modul bencana, dan alat komunikasi. Mereka berpendapat bahwa pemerintah diharapkan 
memberikan atau menyediakan alat peringatan dini bencana, bukan hanya di sekolah tetapi juga di berbagai tempat agar semua penduduk dapat mengetahui apabila bencana alam datang. Mereka juga mengharapkan agar alat-alat tersebut dikontrol apakah masih dapat berfungsi dengan baik atau tidak.

\section{Daftar Pustaka}

Rahmat Agus. (2015). Menejemen Bencana. Tersedia dalam http://web.iaincirebon.

ac.id/ebook/moon/SocialWelfare/Disaster/Manajemen\%20dan\%2 Omitigasi.pdf

Walgito Bimo. (2004). Pengantar Psikologi Umum. Yogyakarta: Andi Offset.

Sungkawa Dadang. (2011). Letak Indonesia (Jurnal). http://file.upi.edu/Direktori/

FPIPS/JUR._PEND._GEOGRAFI/195502101980021DADANG_SU

NGKAWA/letak_Indonesia.pdf. diunduh pada tanggal 12 Desember 2012 jam 07.25 WIB.

DEPKOMINFO. (2008). Memahami Bencana: Informasi Tindakan Masyarakat Mengurangi Resiko Bencana. Jakarta: Badan Informasi Publik Pusat.

Ella dan Usman. (2008). Mencerdasi Bencana. Jakarta: PT. Grasindo.

Garvin, David A., \& Michael A. Roberto. What You Don't Know About Making Dicisions. Havard Business Review 79, No.8 (September 2001):108-116.

L Sjöberg, BE Moen, T Rundmo. (2004). An evaluation of the psychometric paradigm in risk perception research.

Martono Nanang. (2010). Metode Penelitian Kuantitatif. Jakarta: Rajawali Pers.

Masri Singarimbun \& Sofian Efendi. (1982). Metode Penelitian Survey. Yogyakarta: Tiara Wacana.

Miftah Thoha.(1983). Perilaku Organisasi Konsep Dasar dan Aplikasinya. Jakarta. CV. Rajawali.

O. Lange; M. Ivanova; N. Lebedeva. (1991). Geologi Umum (alih bahasa: Eric Jayaporhas Silitonga). Jakarta: Gaya Media Pratama. 
Prambodo S. Arie. (2005). Panduan Praktis Menghadapi Bencana. Yogyakarta: Penerbit Kanisius.

Purnomo Hadi dan Sugiantoro Ronny. (2010). Manajemen Bencana: Respons dan Tindakan terhadap Bencana. Jakarta: Media Pressindo.

Slameto. (2010). Belajar \& Faktor-faktor yang Mempengaruhinya. Jakarta : Rineka Cipta.

Sugihartono. (2007). Psikologi Pendidikan. Yogyakarta: UNY Press.

Triatmadja Radianta. (2010). Tsunami: Kejadian, Penjalaran, Daya Rusak, dan Mitigasinya. Yogyakarta: Gajah Mada University Press.

Undang-undang No. 24 tahun 2007 tentang Penanggulangan Bencana. 